\section{Patents: Universities are right to partner}

I disagree with your groundless suggestion that partnerships between universities and patent firms are "unseemly" (Nature 501, 471-472; 2013). Such partnerships stand to increase the rewards and level of protection for inventors, which are, after all, the purposes of a patent.

Some critics argue that a university's mission should be to disseminate knowledge - in which case, universities are free simply to publish their inventions without patenting them or to seek a patent and offer a free licence. But others choose to patent their inventions to recoup their research dollars and reward their inventors, as the US Bayh-Dole Act encourages. Companies such as Intellectual Ventures in Bellevue, Washington (of which I am founder and vice-chairman), facilitate these choices.

Intellectual Ventures has acquired rights to thousands of university patents and in the past ten years has paid about US $\$ 110$ million to universities and government researchers, $\$ 510$ million to independent inventors and more than $\$ 720$ million to smaller companies. The organization also works with university researchers to launch new businesses. For example, our work with Duke University's Center for Metamaterials and Integrated Plasmonics in Durham, North Carolina, has produced two spin-off companies that have raised tens of millions in venture capital.

Universities are important engines of innovation and sources of pioneering technology, but they are not designed to file costly, lengthy lawsuits. California's Stanford University fought all the way to the Supreme Court in its infringement suit against Roche, the Swiss pharmaceutical giant, only to lose in 2011. Carnegie Mellon University in Pittsburgh, Pennsylvania, has been fighting for years against a company recently adjudged to be a wilful infringer, and that case is going to appeal.

By teaming up with firms that specialize in patent rights, universities have a better chance of reaping the royalties they deserve and focusing on what they do best - education and research.

Peter Detkin Intellectual Ventures, Mountain View, California, USA.

peterd@intven.com Competing financial interests declared: see go.nature.com/ $y$ ksixp for details.

\section{Patents: Universities profit from products}

We believe that the return on investment for universities' intellectual property is enormous - and not only about the bottom line (see Nature 501, 471-472; 2013).

The 1980 Bayh-Dole Act sparked a revolution in US academic innovation by allowing universities to keep their federally funded intellectual property. This has led to more licensing income and royalties for inventors, better funding opportunities as a result of wider research collaborations, and an increasingly entrepreneurial academic culture. Society has benefited from applied research into global challenges, such as health and the environment, from an economy strengthened by licensing revenue and from the well-paid jobs that have been generated by university start-up companies.

Across the United States, universities create an average of two start-ups a day, which tend to last longer and attract more investment than non-university start-ups (see go.nature. com/ojq3fx). A survey by the Association of University Technology Managers in Deerfield, Illinois, revealed that 82 federally funded institutions achieved net product sales of US $\$ 36.8$ billion in the 2012 fiscal year (see go.nature.com/vgtjk4). Among institutions surveyed, the number of cumulative active licences also increased to more than 40,000, and more than 5,000 US patents and almost 6,400 licences and options for new technologies were issued during the year, with 705 start-up companies formed and 591 consumer products created.

University patenting and academic technology transfer have certainly paid off.

Paul R. Sanberg, Valerie L. McDevitt University of South Florida, and National Academy of Inventors, Tampa, USA.

psanberg@usf.edu

\section{Cattle, cheese and conservation}

Indigenous people from the Pantanal region in Brazil have teamed up with scientists to rescue specialized bovine genes and a prized traditional cheese. The Pantanal Bioma Cheese Project (www.biomacheese. blogspot.de) is in line with a worldwide trend in agricultural practice to foster nutrition and health through the conservation of natural ecosystems.

The remarkable Pantaneiro cattle, introduced some 400 years ago by the Portuguese, are genetically resistant to trypanosomiasis, myiasis, worms and ticks, and have survived the region's extreme ecological conditions, ranging from floods and droughts to rough native pastures and jaguar predation. Intermixing with commercial breeds has meant that only 500 of these highly adapted animals are left in genetic isolation. Also under threat is the Nicola cheese prepared from their milk.

Scientists propose a certification of origin for the cattle, underpinned by markerassisted selection of genetic polymorphisms associated with the cows' milk composition and high yield, and with their 'thrifty' phenotype. Embryos and semen from selected animals will be available to local farmers for breeding.

This will help to save these cattle from extinction and help to conserve the life and traditions of the Pantanal people. The Pantanal Bioma is included in UNESCO's World Heritage and Man and the Biosphere programmes.

Sergio Ulhoa Dani, Marcus Vinicius Morais de Oliveira Pantanal Bioma Cheese Project Consortium, Aquidauana, Brazil. srgdani@gmail.com

S. U.D. declares competing financial interests: see go.nature. com/rznbigfor details.

\section{Scientific software needs quality control}

As computational tools become more important for researchers, we contend that the verification and validation of researcher-built software should happen long before it is published (Nature 501, 472; 2013).

The time and effort needed to fix errors increases exponentially the later they are identified. Exposing such computational errors only when a research paper is peer reviewed threatens to undo years of hard work.

To unlock the full potential of computer-based science, software engineering must be at peak quality throughout. This depends on linking computer modelling with reality, demonstrating fitness for purpose, tracking and understanding scientific abstractions and assumptions, and considering all these factors when weighing up the value of software-derived results.

Software-based science is necessarily cross-disciplinary: scientists ensure that the research is relevant and software engineers make sure that it is correct. Their skills should be combined from the outset. Kieran Alden University of Birmingham, UK. k.j.alden@bham.ac.uk Mark Read Charles Perkins Centre, University of Sydney, Australia. 